\title{
Asian

RESEARCH PAPER

\section{Studies on germination, seedling morphology and vigour index of coriander (Coriandrum sativum L.) genotypes}

\author{
J.E. ADELINE VINILA*, P. PARAMAGURU AND G. VAIDEHI \\ Horticultural College and Research Institute, COIMBATORE (T.N.) INDIA
}

\begin{abstract}
A field experiment was carried out to screen the coriander germ plasm for germination studies at Horticultural College and Research Institute, TNAU, Coimbatore. Preliminary screening was done with 240 accessions and 50 accessions were selected based on yield performance along with check $\mathrm{CO}(\mathrm{Cr}) 4$ and the seeds were sown in pots. The experiment was carried out with three replications in Randomized Block Design. Germination percentage, Height of the seedlings, Root Length and Vigour index were maximum in accession (ACC 18) compared to check.
\end{abstract}

Key Words : Coriander, Germination, Vigour

View point paper : Vinila, J.E. Adeline, Paramaguru, P. and Vaidehi, G. (2016). Studies on germination, seedling morphology and vigour index of coriander (Coriandrum sativum L.) genotypes. Asian Sci., 11 (1): 14-17, DOI : 10.15740/HAS/AS/11.1/14-17

\footnotetext{
* Author for correspondence

J.E. Adeline Vinila, Horticultural College and Research Institute, COIMBATORE (T.N.) INDIA
} 